\title{
CHARACTERIZATION OF THE S PROTEIN OF ENTEROTROPIC MURINE CORONAVIRUS STRAIN-Y
}

\author{
Susan R. Compton and Satoshi Kunita* \\ Section of Comparative Medicine \\ Yale University School of Medicine \\ New Haven, Connecticut
}

\begin{abstract}
The pathogenesis of enterotropic murine coronavirus strain MHV-Y differs extensively from that of prototypic respiratory strains of murine coronaviruses. The $\mathrm{S}$ protein of MHV-Y was characterized as a first step towards identifying viral determinants of enterotropism. Immunoblots of MHV-Y virions using anti-S protein specific antiserum revealed that the MHV-Y S protein was inefficiently cleaved. The MHV-Y S gene was cloned and sequenced. It encodes a protein predicted to be 1361 amino acids long. The presence of several amino acids changes within and surrounding the predicted cleavage site of the MHV-Y S protein may contribute to its inefficient cleavage.
\end{abstract}

\section{INTRODUCTION}

Mouse hepatitis virus (MHV), a singular name for several murine coronaviruses, causes a wide spectrum of diseases ranging from mild enteritis or rhinitis to fatal hepatitis or encephalitis. MHV strains can be divided into two biotypes, respiratory and enterotropic, on the basis of their initial site of replication. Following oronasal inoculation, respiratory MHV strains initiate replication in the upper respiratory tract and then disseminate to multiple organs if the mouse is sufficiently susceptible due to age, genotype or immune status ${ }^{1,2}$. On the other hand, replication of enterotropic MHV strains, such as MHV-Y, is largely restricted to the intestinal mucosa, with minimal or no dissemination to other organs ${ }^{3,4}$. All ages and genotypes of mice are susceptible to infection with enterotropic MHV-Y but only young mice develop disease in the form of enteritis ${ }^{3,4}$. Unlike respiratory MHV strains in which viral titers mirror

\footnotetext{
${ }^{*}$ Current address: Institute of Laboratory Animal Research, School of Science, Kitasato University, Kanagawa, Japan.
} 
the severity of lesions, the titers of MHV-Y produced in the intestines do not reflect the level of lesion formation ${ }^{1,4}$.

The molecular basis of MHV pathogenesis has been studied extensively for respiratory MHV strains such as MHV-4/JHM and MHV-A59. Although the molecular mechanisms of tissue tropism are still not clear, several studies have shown an important role for the MHV S protein in virulence and tissue tropism ${ }^{2}$. The $\mathrm{S}$ glycoprotein is synthesized as an 170-200 kD glycoprotein which is cleaved by trypsin-like host proteases into two $90 \mathrm{kD}$ subunits. Cleavage is dependent on the virus strain and host cell type in which virus was grown. The $\mathrm{S}$ protein forms the characteristic viral peplomers and is believed to be responsible for the initiation and spread of infection, by mediating attachment of the virus to cell surface receptors and by inducing cell-cell fusion. The $\mathrm{S}$ protein also elicits neutralizing antibodies and cellular immune responses ${ }^{2}$. Variant viruses which possess mutations or deletions in the $\mathrm{S}$ protein have altered target cell specificity, rates of spread or virulence ${ }^{5-11}$. In contrast to respiratory MHV strains, the viral factors which determine the tropisms of enterotropic MHV strains have not been identified. The $\mathrm{S}$ protein of MHV-Y was characterized molecularly as a first step in determining the role of the $\mathrm{S}$ protein in the restricted tissue tropism of MHV-Y.

\section{MATERIALS AND METHODS}

\section{Viruses and Cells}

MHV-Y was originally isolated in NCTC 1469 cells from the intestine of a naturally infected infant mouse with acute typhlocolitis ${ }^{12}$. MHV-A59 was obtained from American Type Culture Collection. Virus stocks used in these studies were generated in J774A.1 cells. J774A.1 cells were obtained from American Type Culture Collection and maintained in RPMI medium 1640 supplemented with $10 \%$ fetal bovine serum.

\section{Immunoblotting}

Purified virion proteins were separated on $8 \%$ SDS-PAGE gels, electroblotted to nitrocellulose sheets and were probed with monospecific polyclonal goat antiserum to the $\mathrm{S}$ protein of MHV-A59 (gift of K. Holmes). Bound antibody was detected with peroxidaseconjugated Staphylococcal protein A and chemiluminescent reagents.

\section{cDNA Cloning}

Virion purified from MHV-Y infected J774A.1 supernatants were diluted in buffer containing RNasin and RNA was purified by SDS/Proteinase $\mathrm{K}$ treatment, phenol-chloroform extraction and ethanol precipitation. Virion RNA was reverse transcribed and PCR-amplified using the GeneAmp RNA PCR kit (Perkin Elmer) according to the manufacturers instructions. The MHV-Y S gene was PCR amplified in three overlapping fragments. Primer sets used to amplify the 5' and 3' end of the S gene were designed on the basis of the published S gene sequences of MHV-A59 and MHV-JHM and primer set used to amplify the central portion of the $S$ gene was designed on the basis of sequences determined from clones of the 5' and 3' ends of the MHV-Y S gene ${ }^{13,14}$. The PCR products were cloned into the $\mathrm{PCR}^{\mathrm{TM}} \mathrm{II}$ cloning vector using the TA cloning kit (Invitrogen). 


\section{DNA Sequencing}

The sequence of the MHV-Y S gene was determined in both directions from double stranded plasmid DNA. To exclude sequence errors based on misincorporation by the Taq polymerase, multiple clones from different RT-PCR reactions were sequenced and the consistency of the sequence was confirmed in at least 3 clones. Sequence comparisons were performed with the aid of the Translate, Gap, Bestfit, Pileup, Pretty and Peptidestructure programs in the Genetic Computer Group Sequence Analysis Software Package. Glycosylation sites were defined by the motif NXT or NXS where X does not equal P.

\section{RESULTS AND DISCUSSION}

As a first step in the characterization of the MHV-Y S protein, an immunoblot of proteins from MHV-Y virions grown in J774A.1 cells was performed using monospecific polyclonal antiserum specific for the $\mathrm{S}$ protein (Figure 1). The immunoblot showed negligible amounts of cleaved MHV-Y S protein subunits. A low to undetectable level of cleavage of the MHV-Y S protein was also seen in purified MHV-Y virions treated with trypsin, cell lysates from MHV-Y infected J774A.1 cells and homogenates of MHV-Y infected infant mouse intestines.

Given the lack of efficient cleavage of the MHV-Y S protein, we wanted to determine whether a functional cleavage site existed in the MHV-Y S protein. The entire MHV-Y S gene was cloned in three overlapping fragments and clones were characterized by restriction enzyme mapping. Cleavage patterns for the MHV-Y clones differed substantially from those predicted from MHV-A59 and MHV-4/JHM S sequences, so the entire MHV-Y S gene was sequenced ${ }^{13-15}$.

Figure 1. Immunoblots of MHV-A59 and MHV-Y virions. Virion proteins were

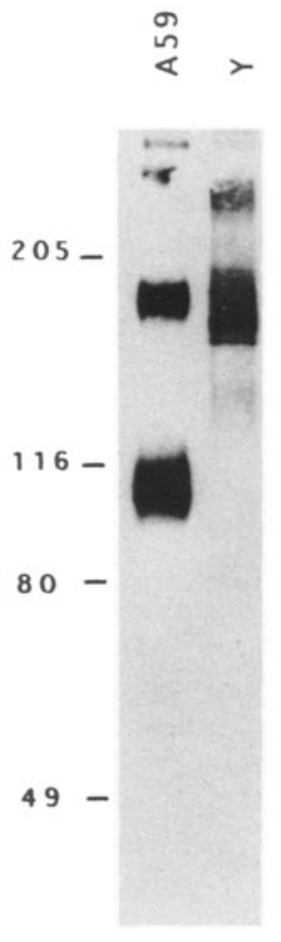
separated on an $8 \%$ SDS-PAGE gel (Lanes: 1 , MHV-A59 virions; 2 , MHV-Y virions) and were probed with monospecific polyclonal goat antiserum to the $S$ protein of MHV-A59. Bound antibody was detected with peroxidase-conjugated Staphylococcal protein A and chemiluminescent reagents. Positions of prestained protein markers are indicated on the margin. 
Table 1. Summary of S gene characteristics

\begin{tabular}{lccc}
\hline & MHV-4 & MHV-A59 & MHV-Y \\
\hline Nucleotides & 4128 & 3972 & 4083 \\
Amino acids-total & 1376 & 1324 & 1361 \\
$\quad$-S1 & 769 & 717 & 757 \\
-S2 & 607 & 607 & 604 \\
Pot. N-glycos. sites & 22 & 21 & 22 \\
Cleavage site & dysksRRARR/S & dysksRRAHR/S & nysttHRARR/S \\
\hline
\end{tabular}

The predicted MHV-Y S protein is 1361 amino acids long, 15 amino acid shorter than the MHV-4 S protein (Table 1). The 12 amino acids deleted in the S1 subunit of MHV-Y S protein were localized in 3 separate sites (amino acids 492, 515-522 and 574-576) within the region deleted in the MHV-JHM S protein ${ }^{14}$. The 3 amino acid deletion (amino acids 911-913) in the S2 subunit of the MHV-Y S protein is the first reported deletion in the S2 subunit of any MHV strain, though this deletion lies within a 7 amino acid region deleted from the $\mathrm{S}$ proteins of bovine coronaviruses and human coronavirus strain $\mathrm{OC} 43^{16-18}$. Even though the $\mathrm{S} 2$ deletion maps to the region of the binding sites of monoclonal antibodies 5B19.2 and 5B170.3, both antibodies were capable of neutralizing MHV-Y infectivity in J774A.1 cells ${ }^{19,20}$. All four deletions found in the tissue culture-derived MHV-Y stocks were confirmed in cDNA clones derived from intestinal virus stocks of MHV-Y.

The nucleotide and amino acid sequence identities between MHV-Y and either MHV-4 or MHV-A59 (approximately $81 \%$ and $84 \%$ respectively) were lower than between MHV-4 and MHV-A59 (89\% and $92 \%$ respectively). The MHV-Y S protein has 22 predicted glycosylation sites (Table 1), the same number predicted for the MHV-4 S protein, but the positions of only 20 predicted glycosylation sites for the MHV-Y S protein were conserved $^{14,15}$. The predicted glycosylation sites at amino acids 582 and 709 of MHV-4 were absent from the MHV-Y S protein and were replaced by predicted glycosylation sites at amino acids 575 and 756 of the MHV-Y S protein. The N-terminal signal peptide located at amino acids 1 to 17 in the MHV-Y S protein was conserved relative to that of the MHV-4 S protein $^{14,15}$. The hydrophobic membrane anchor sequence located at amino acids amino acids 1307 to 1322 of the MHV-Y S protein was also conserved. The KWPWYVWL motif found in all coronavirus $\mathrm{S}$ proteins was present in the MHV-Y S protein between amino acids 1299 and $1306^{17}$.

The sequence adjacent to and including the cleavage signal sequence for the MHV-Y $S$ protein (Table 1), differs from the sequence present in other MHV S proteins in several ways $^{13-15}$. First, the MHV-Y S protein cleavage signal sequence differs from the consensus cleavage signal by the replacement of an arginine with a histidine (HRARR instead of RRARR). The presence of a histidine in this particular position within the cleavage signal sequence may alter interactions between the MHV-Y S protein and the active site of cellular proteases resulting in negligible MHV-Y S protein cleavage. Alternatively, the MHV-Y S protein signal cleavage signal (HRARR) may be functional but because of other changes in the region, this signal is not accessible to proteases. The KS to TT change at positions -6 and -7 relative to the cleavage site and/or the addition of a potential glycosylation site (NYS) at position -10 relative to the cleavage site may cause conformational changes within the protein resulting in the inaccessibility of the cleavage signal sequence to the trypsin-like proteases which cleave most MHV S proteins. It is interesting to note that even though the MHV-Y S protein is inefficiently cleaved, it still efficiently induces cell-cell fusion in many types of cells in culture and in vivo in the intestinal mucosa (unpublished data). This 
observation agrees with recent results indicatıng that cleavage of MHV S proteins may increase the efficiency of fusion but is not essential for fusion induction ${ }^{172628}$

\section{ACKNOWLEDGMENTS}

We thank Frank Coyle for technical assistance and Lisa Ball-Goodrich for many helpful discussions This work was supported by NIH grant \#RR02039

\section{REFERENCES}

1 Barthold S W, Smith A L Response of genetically susceptible and resistant mice to intranasal inoculation with mouse hepatitis virus JHM Virus Res 1987,7 225-239

2 Compton S R, Barthold S W, Smith, A L The cellular and molecular pathogenesis of coronaviruses Lab Anım Sc1 1993,43 15-28

3 Barthold S W Host age and genotypic effects on enterotropıc mouse hepatitıs virus infection Lab Anım Sc1 1987,37 36-40

4 Barthold S W, Beck D S, Smith A L Enterotropic coronavirus (mouse hepatitis virus) in mice influence of host age and strain on infection and disease Lab Anım Sc1 1993,43 276-284

5 Dalzıel R G, Lampert PW, Talbot P J , Buchmeıer, M J Site-specific alteration of murıne hepatitıs virus type 4 peplomer glycoprotein E2 results in reduced neurovirulence J Virol 1986,59 463-471

6 Flemıng J O , Trousdale M D , El-Zaatarı F A K, Stohlman S A , Weıner, L A Pathogenıcity of antıgenıc variants of murine coronavirus JHM selected with monoclonal antıbodies J Virol 1986,58 869-875

7 Wege H, Winter J, Meyermann R The peplomer proteın E2 of coronavirus JHM as a determınant of neurovirulence Definition of critical epitopes by varıant analysis J Gen Virol 1988,69 87-98

8 Gallagher T M , Parker S E, Buchmeier, M J Neutralızatıon-resıstant varıants of a neurotropıc coronavirus are generated by deletions within the amıno-termınal half of the spike glycoprotein $\mathrm{J}$ Virol 1990,64 731-741

9 Fazakerley J K, Parker S E, Bloom F, Buchmeıer, M J The V5A13 1 envelope glycoprotein deletion mutant of mouse hepatitis virus type-4 is neuroattenuated by its reduced rate of spread in the central nervous system Virology 1992,187 178-188

10 Wang F-I , Fleming J O, La1 M M C Sequence analysis of the spike protein gene of murıne coronavirus variants Study of genetic sites affectıng neuropathogenıcity Virology 1992,186 742-749

11 Hingley S T, Gombold J L, Lavi E, Weiss, S R MHV-A59 fusion mutants are attenuated and display altered hepatotropism Virology 1994,200 1-10

12 Barthold S W, Smith A L, Lord PFS, Bhatt PN, Jacoby R O, Main A J Epızootıc coronaviral typhlocolitıs in sucklıng mice Lab Anım Sc1 1982,32 376-383

13 Luytjes W, Sturman L S, Breedenbeek P J , Charıte J, van der Zeıjst B A M , Horzınek M C, Spaan W J M Primary structure of the glycoprotein E2 of coronavirus MHV-A59 and identification of the trypsin cleavage site Virology 1987,161 479-487

14 Schmidt I, Skınner M A , Siddell, S G Nucleotide sequence of the gene encoding the surface projection glycoprotein of the coronavirus MHV-JHM J Gen Virol 1987,68 47-56

15 Parker S E, Gallagher T M, Buchmeier, M J Sequence analysıs reveals extensıve polymorphısm and evidence of deletions within the E2 glycoprotein gene of several strains of murıne hepatitis virus Virology 1989,173 664-673

16 Abraham S, Kienzle TE, Lapps W, Brıan D A Deduced sequence of the bovine coronavirus spike protein and identification of the internal proteolytic cleavage site Virology 1990,176 296-301

17 Boireu P, Cruciere C, LaPorte J Nucleotide sequence of the glycoprotein S gene of bovine enteric coronavirus and comparison with the $S$ proteins of two mouse hepatitis virus strains $J$ Gen Virol $1990,71487-492$

18 Kunkel, F, Herrler, G Structural and functional analysis of the surface protein of human coronavirus OC43 Virology 1993,195 195-202

19 Luytjes W, Geerts D, Posthumus W, Meleon R, Spaan W Amıno acid sequence of a conserved neutralızıng epitope of murıne coronaviruses J Virol 1989,63 1408-1412

20 Danıel C, Anderson R, Buchmeıer M J , Flemıng J O , Spaan W J , Wege H , Talbot, P J Identıficatıon of an immunodominant linear neutralization domain on the S2 portion of the murine coronavirus spike 
glycoproteın and evidence that it forms part of a complex tridımensional structure J Vırol 1993,67 11851194

21 Gombold J L , Hingley S T, Weiss, S R Fusion-defective mutants of mouse hepatitis virus A59 contain a mutation in the spike protein cleavage signal J Virol 1993,67 4504-4512

22 Stauber R, Pfleiderer M, Siddell S Proteolytic cleavage of the murıne coronavirus surface glycoprotein is not required for fusion activity J Gen Virol 1993,74 183-191

23 Taguch $1 \mathrm{~F}$ Fusion formation by the uncleaved spike protein of murine coronavirus JHMV variant cl-2 J Virol 1993,67 1195-1202 